\title{
Designing colonial theme restaurant reflecting the British era of Kolkata
}

\author{
SWETABAHEN MESARIA AND NEERJA JAISWAL
}

Received: 14.05.2014; Accepted: 16.11.2014

See end of the paper for authors' affiliations SWETABAHEN MESARIA Department of Family and Community Resource Management, Faculty of Family and Community Sciences, The Maharaja Sayajirao University of Baroda, VADODARA (GUJARAT) INDIA

Email: sweta_mesaria@yahoo. com
ABSTRACT : The present design project was undertaken with the objectives, (a) to identify the famous historical monuments of British era in Kolkata, (b) to study the design elements used in the interiors of these selected historical monuments, (c) to design a colonial theme Restaurant reflecting British era of Kolkata in Vadodara city. and (d) to estimate the cost of the design developed for the theme project. The observation sheets were used to gather the details for developing case studies on the existing interior features of the wall and its treatment, floor and its treatment, ceiling and its treatment, furniture and furnishings, lighting and accessories of the selected British colonial monuments of Kolkata and the existing status of the restaurant "Trident" of the Revival Lord's Inn at Vadodara. The proposed design project included the schedule of two dimensional drawings made with the support of "AUTO CAD" version 2005-06. The three dimensional drawings were created from new software called "Autodesk Inventor" version 2009. Based on the developed case studies on colonial British era monuments of Kolkata, the flooring, walls, ceiling, lightings and accessories of the selected restaurant at Vadodara was designed. The designing of the present project would be useful as a resource material for the staff, students and institutions pursuing interiors as one of the subjects in their curriculum. It would also be useful for the professionals in the field of Interiors.

KEY WORDS: Restaurant, Theme, Colonial, Design

- HOW TO CITE THIS PAPER : Mesaria, Swetabahen and Jaiswal, Neerja (2014). Designing colonial theme restaurant reflecting the British era of Kolkata. Asian J. Home Sci., 9 (2) : 620-623. 